\title{
A TRIPARTIÇÃO DA FILOSOFIA NA IDADE MÉDIA E ANTIGÜIDADE E SUAS FONTES EM PLATÃO
}

\author{
MARCOS MARTINHO DOS SANTOS* \\ Faculdade de Filosofia, Letras e Ciências Humanas \\ da Universidade de São Paulo
}

\begin{abstract}
RESUMO: Pretende-se mostrar como as duas acusações que Sócrates refuta na Apologia e a defesa mesma que lá confirma se inserem em sistema que reparte e reúne as partes da filosofia. Para tal, começa-se pelas partiçóes da filosofia propostas por scriptores artium tardios e, aos poucos, faz-se-as remontar às fontes antigas, que estão, de modo geral, nos filósofos gregos e romanos e, de modo particular, em Platão, no contexto das referidas acusações e defesa da Apologia de Sócrates.
\end{abstract} PALAVRAS-CHAVE: partes da filosofia; tripartição da filosofia; Platão; Apologia de Sócrates.

Ergo cum tripertita sit philosophia, [...] incipiamus (SEN. Ep. 89 14)

Logo, já que é tripartida a filosofia, [...] comecemos.

\section{A tripartição da filosofia nos scriptores artium}

Das partições da filosofia que os scriptores artium tardios propuseram a mais completa parece ser a que se lê na Eruditio didascalica de Hugo de São Vítor (séc. XII d.C.). Antes de tudo, Hugo atenta para a partição da natureza humana, que constaria de bem e mal, e diz que o bem deve ser preservado, o mal, extirpado, se não ao menos atenuado (Hug. Erud. 1 6); em outras palavras, atenta para duas ações, que qualifica respectivamente como divina e humana (id. ib. 19 ). Mas se a parte do mal é simples, já que a natureza humana se distingue da divina pela simples forma, a do bem é dupla, já que aquela se assemelha a esta pela verdade e virtude (id. ib. 1 6.9). Assim, da ação divina a speculatio veritatis, ou "contemplação da verdade", provê-nos do bem, e o exercitium virtutis, ou "exercí- 
cio da virtude", precavê-nos contra o mal, resguardando o bem; já da ação humana a administratio corporis, ou "administração do corpo", remedeia o mal (id. ib. 1 9). Enfim, Hugo atenta para três ações que se perfazem, respectivamente, no espírito, alma e corpo.

De outro modo, atenta para três outras ações, que se perfazem, já não nas partes da natureza humana, mas naquelas da natureza universal, de que a mesma natureza humana é apenas uma das partes; em outras palavras, atenta para as ações que se perfazem, já não no microcosmo, mas no cosmo. Diz, então, que se devem considerar a ação de Deus, a ação da natureza e a ação do homem, respectivamente referidas nos seguintes passos do texto bíblico (id. ib. 1 10):

\section{In principio creavit Deus coelum et terram [Gn 1,1]}

No princípio criou Deus céu e terra;

Producat terra herbam virentem [Gn 1,11]
Produza a terra a erva verdejante;

Consuerunt folia ficus, et fecerunt sibi perizomata [Gn 3,7]

Coseram folhas de figueira e fizeram cinturões para si.

Com o verbo creare, pois, indica-se a ação de originar algo do nada, o que só Deus pode (id. ib.). Com o verbo producere, a ação de manifestar as virtualidades de algo, ou ainda, atuar as potências de algo, de modo que a natureza, diferentemente de Deus, necessita de matéria-prima para originar algo (id. ib.). Com o verbo facere, a ação que sintetiza as anteriores, pois que o homem, à semelhança da natureza, também necessita de matéria-prima para originar algo; à semelhança de Deus, porém, origina da matéria-prima algo que, não estando latente nesta, parece originar-se do nada (id. ib.). Por exemplo, do nada Deus criou a terra; da terra a natureza produziu a figueira, e da figueira as folhas; das folhas o homem fez, não o fruto, que lá jazia e seria atuado pela natureza, mas o cinturão, que se fez, por assim dizer, do nada.

De outro modo, enfim, diz Hugo que das coisas umas não têm princípio nem fim - são as eternas -; outras têm princípio, mas não fim - são as perpétuas -; outras, enfim, têm princípio e fim - são as temporais - (id. ib. 1 7). Então, do microcosmo prender-se-iam a contemplação da verdade, que se dá no espírito, às coisas eternas, e o exercício da virtude, que se dá na alma, às coisas perpétuas, e 
a administração do corpo, que se dá no corpo, às coisas temporais; do cosmo, por sua vez, prender-se-iam às coisas eternas, perpétuas e temporais, respectivamente, a ação de Deus, a ação da natureza e a ação do homem.

Ora, daí vem a primeira partição da filosofia proposta por Hugo: de um lado, a sapientia, parte dupla, que trataria das coisas que não têm fim, isto é, das coisas eternas e das perpétuas; de outro, a scientia, parte simples, que trataria das coisas que têm fim, isto é, das temporais. À sapientia, pois, prendem-se a parte chamada theorica ou speculativa e a chamada practica ou activa; à scientia, por sua vez, a parte chamada mechanical (id. ib. 19 ; cf. 2 19). Daí, à parte theorica respeitam a contemplação da verdade e a ação de Deus; à practica, o exercício da virtude e a ação da natureza; à mechanica, a administração do corpo e a ação do homem.

A essas três partes, porém, Hugo acresce outra, que entende, assim, não como desdobramento, mas como complemento daquelas. Pois se cada uma das três partes da filosofia atenta para coisas distintas, todas, porém, necessitam de um método ou via que as habilite a discernir as coisas por meio do juízo [dialectica] e, então, expor o juízo por meio do discurso [grammatica]; a nova parte da filosofia é, pois, a logica² (id. ib. 1 12; cf. 2 29).

Tal é, em suma, a primeira partição da filosofia proposta por Hugo: de um lado, as partes teórica, prática e mecânica; de outro, a lógica (id. ib. 1 13; 2 2). Tal partição, porém, diz Hugo ainda que se pode rearranjar. Para tal, basta que se conjuguem as partes prática e mecânica, por atentar ambas para a conduta, ou melhor, para a intenção, que se dá na alma [prática], e para a ação, que se dá no corpo [mecânica]; assim, obtém-se a seguinte tripartição da filosofia: a parte da especulação, a que corresponde a teórica; a da ação, a que correspondem a prática e mecânica ${ }^{3}$; a do julgamento e discurso, a que corresponde a lógica (id. ib. 2 19).

$\mathrm{Na}$ verdade, foi assim arranjada que os scriptores artium mais ou menos tardios propuseram, o mais das vezes, a primeira partição da filosofia, embora nomeando a parte teórica por naturalis ou physica, e a prática por moralis ou ethica ${ }^{4}$. É o que se vê do Metalógicoe Dos sete setenários de João de Salesbury (séc. XII d.C.):

Natae sunt ergo duae partes philosophiae, naturalis et moralis, quae, aliis nominibus, physica et ethica appellantur. Sed quia per imperitiam disserendi, multa inconvenientia colligebant, $[. .$.$] necesse fuit investigari$ et promulgari scientiam, quae discretionem faceret vocum et intellectuum, et fallaciarum nubeculas dissiparet. Et hic quidem, sicut Boetius in 
commento secundo Super Porphyrium asserit, est ortus logicae disciplinae (SARESB. Met. 2 2)

Nasceram, logo, duas partes da filosofia, a natural e a moral, que, com outros nomes, se chamam física e ética. Mas porque contavam [os peripatéticos] muitas divergências por imperícia no dissertar, [...] foi necessário investigar e promulgar uma ciência que fizesse o discernimento das vozes [= gramática] e intelecções [= dialética] e dissipasse as névoas da falácia. E aqui, sim, como assevera Boécio [séc. V-VI d.C.] no segundo comentário Sobre Porfírio [cap. 1], está a origem da disciplina lógica;

Tres itaque facultates, naturalis, moralis, et rationalis, materiam praestant, quia singulae suas exponunt quaestiones. Quaerit enim ethica, parentibus magis, an legibus oporteat obedire, si forte dissentiant. Physica, an mundus aeternus sit, aut perpetuus aut initium habuerit, et sit finem habiturus in tempore, aut sit nihil horum. Logica, an contrariorum sit eadem disciplina, quoniam eorum idem sensus. Quaerunt ergo singulae, et licet suis muniantur principiis, eis tamen logica methodos suas, compendii scilicet rationes, communiter subministrat, unde non modo ad exercitationem, sed ad obviationes, et ad, secundum philosophiam, disciplinas utilissima est (id. ib. 2 13; cf. Sept. 7)

E assim três faculdades, a natural, a moral e a racional, apresentam matéria, porque expõem questões singulares. Pois a ética questiona se importa obedecer mais aos pais ou às leis, se acaso dissentirem aqueles destas. A física [questiona] se o mundo é eterno, ou perpétuo, ou tem início e há de ter fim no tempo, ou nada disso. A lógica [questiona] se é a mesma a disciplina de coisas contrárias, pois que é o mesmo o sentimento destas. Questionam, logo, singularmente, e, apesar de se munirem de princípios seus, àquelas, todavia, a lógica ministra em comum seus métodos, ou seja, arrazoados compendiosos, de onde [vem que] é muito útil não só à exercitação mas às vias e às disciplinas que seguem a filosofia;

é o que se vê, também, das Origens de Isidoro de Sevilha (séc. VI-VII d.C.):

Philosophiae species tripertita est: una naturalis, quae Graece Physica appellatur, in qua de naturae inquisitione disseritur: altera moralis, quae Graece Ethica dicitur, in qua de moribus agitur: tertia rationalis, quae Graeco vocabulo Logica appellatur, in qua disputatur quemadmodum 
in rerum causis vel vitae moribus veritas ipsa quaeratur. In Physica igitur causa quaerendi, in Ethica ordo vivendi, in Logica ratio intellegendi versatur (IsID. Orig. $2243-4$ )

Da filosofia a espécie é tripartida: uma a natural, que em grego se chama physica, em que se disserta da inquirição da natureza; outra a moral, que em grego se diz ethica, em que se debate sobre os costumes; terceira a racional, que com o vocábulo grego se chama logica, em que se disputa sobre como inquirir-se a verdade mesma nas causas das coisas [=física] ou costumes da vida [=ética]. $\mathrm{Na}$ física, logo, versa-se a causa da inquirição; na ética, a ordem da vida; na lógica, a razão da intelecção;

é o que se vê, enfim, da Instituição dos estudos humanos de Cassiodoro (séc. VI d.C.):

Artium aliae sunt positae in inspectione, id est cognitione et aestimatione rerum, qualis est astrologia: nullum exigens actum, sed ipso rei cujus studium habet, intellectu contenta, quae $\theta \varepsilon \omega \rho \eta \tau \imath \kappa \dot{\alpha}$ vocatur. Alia in agendo, cujus in hoc finis est, ut ipso actu perficiatur, nihilque post actum operis relinquat, quae $\pi \rho \alpha \kappa \tau \iota \kappa \hat{\alpha}$ dicitur, qualis saltatio est. Alia in effectu, quae operis, quod oculis subjicitur consummatione, finem accipiunt [sic], quam $\pi$ o $\imath \eta \tau \imath \kappa \hat{\alpha} v$ appellamus, qualis est pictura (CAssiod. Hum. litt. 2)

Das artes umas se põem na inspeção, isto é, no conhecimento e estimativa das coisas, qual a astrologia, que nenhum ato exige, mas se contenta da intelecção mesma da coisa cujo estudo detém, denominando-se theoretiké. Outra [se põe] no agir, e está o fim dela em que se perfaça pelo ato mesmo e nada deixe após a atuação da obra, dizendo-se praktiké, qual a dança. Outra [se põe] no efeito e atinge [seu] fim na consumação de obra que se sujeita aos olhos, chamando-se poietiké, qual a pintura.

\section{A tripartição da filosofia nos filósofos gregos e romanos}

Na verdade, a tripartição da filosofia foi legada aos scriptores artium pelos filósofos gregos e romanos, ou melhor, pelos estóicos (cf. nota 4), seja seguidores romanos seja fundadores gregos, e por Aristóteles. 


\subsection{Nos estóicos}

Do legado estóico testemunhou Diógenes Laércio já no séc. III d.C., quando era ainda incipiente a tradição patrística em que se filiariam os scriptores artium. Pois, nas Vidas, após preceituar, em geral, a tripartição da filosofia:

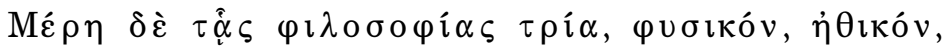

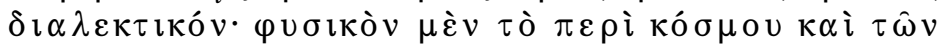

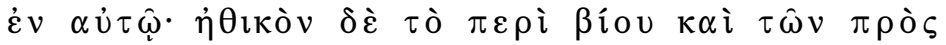

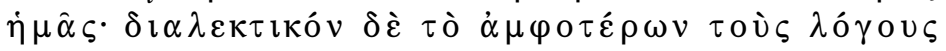 $\pi \rho \varepsilon \sigma b \varepsilon \hat{\text { ov }}$ (DL 1 18) \\ Ora, as partes da filosofia são três: a física, a ética, a lógica. A física [é] aquela acerca do mundo e do que nele há; a ética, aquela acerca da vida e do que se tem a nós; a lógica, aquela que se encarrega dos arrazoados de ambas,}

atribui o preceito, em particular, aos estóicos (id. 7 39-41).

Na verdade, não só os scriptores artium mas muitos filósofos gregos e romanos tomaram a tripartição da filosofia aos estóicos. Assim, de modo geral, alguns filósofos cínicos (ARIST. I 354). Assim, de modo particular, Sexto Empírico (séc. III d.C.), filósofo céptico, quando divide suas obras em partes correspondentes às da filosofia, atribui aos estóicos a tripartição da filosofia. Por exemplo, quando, nas Sublinhas pirrônicas, divide em três partes o exame que o skeptikósfaz do dogmatikós, a fim de discutir o que este diz, primeiro, da lógica (SeXT. P. 2 13), depois, da física (id. ib. 3 1.167) e, enfim, da ética (id. ib. 3 168), assim diz:

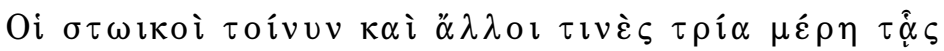

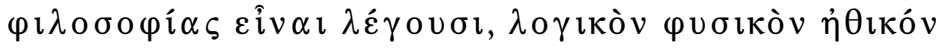 (id. ib. 2 13) \\ Os estóicos, então, e alguns outros dizem ser três as partes da filo- sofia: lógica, física, ética.}

Quando escreve um Contra os lógicos, um Contra os físicos e um Contra os éticos e, naquele, se propõe discutir as partes da filosofia (id. L. 1 2), diz que das várias partições (id. ib. 12 ), propostas por muitos (id. ib. 1 5-15), a mais acabada é a ternária, em tò physikón, tò ethikón e tò logikón (cf. nota 4), proposta pelos estóicos (id. ib. 1 16; cf. ARIST. I 354). Assim também, Cícero (séc. I a.C.), filósofo acadêmico, diz: 
Totam philosophiam tris in partis diviserunt, quam partitionem a Zenone esse retentam videmus (CIC. Fin. 42 4: ZEN. 145 )

Dividiram [os velhos acadêmicos] a filosofia toda em três partes, a qual partição vemos ter sido sustentada por Zenão.

Ora, muitos são os preceitos dos estóicos referentes à tripartição da filosofia. Primeiro, preceituam a simples divisão da filosofia em três partes ${ }^{6}$; assim Zenão de Cício (séc. IV-III a.C.), como se vê do passo sobrecitado de Cícero, parte da doxografia do príncipe dos estóicos (ZEN. 145 ); assim Zenão de Tarso (séc. III-II a.C.):

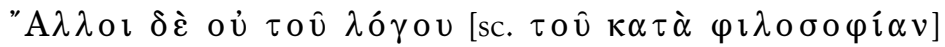
$\tau \alpha \hat{v} \tau \alpha \mu \varepsilon \rho \eta \varphi \alpha \sigma i v$ [sc. logicam, physicam, ethicam], $\dot{\alpha} \lambda \lambda$ '

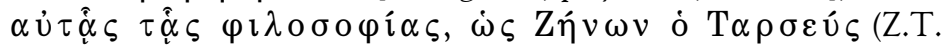
III 3; cf. III 4)

Já outros declaram ser tais partes, não do arrazoado [filosófico], mas da filosofia mesma, como Zenão de Tarso.

Depois, nomeiam cada parte, chamando uma ética ou moral, outra física ou natural, outra lógica ou racional (cf. nota 4); assim Zenão de Cício e Crisipo (séc. III a.C.) e Diógenes da Babilônia (séc. III-II a.C.) e Apolodoro de Seleucia (séc. III a.C.) e Posidônio (séc. II-I a.C.) e Êudromo (séc. inc.):

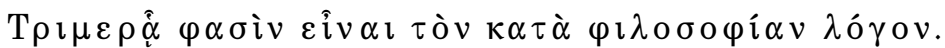

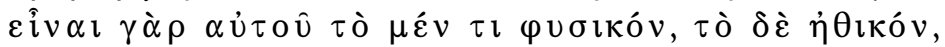

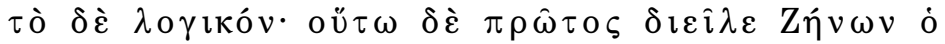

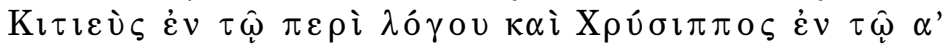

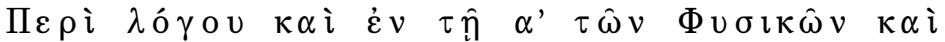

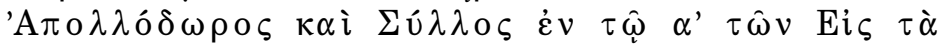

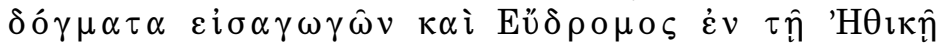

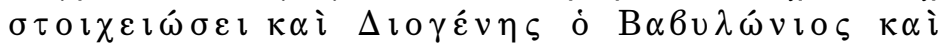

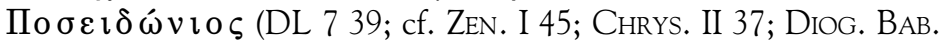
III 16; Apd. Sel. III 1; Eudr. III 1)

Declaram [os estóicos] ser tripartido o arrazoado filosófico, pois dele há algo físico, algo ético, algo lógico. Assim primeiro distingue Zenão de Cício em Do lógos, e Crisipo no primeiro [livro] de Do lógos e na primeira [seção] das Coisas físicas, e Apolodoro, e Silo no primeiro [livro] das Introduções às opiniões, e Eudromo nos Elementos éticos, e Diógenes da Babilônia, e Posidônio; 


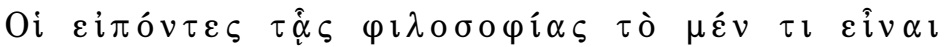

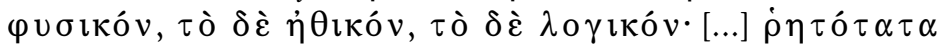

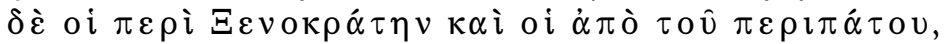

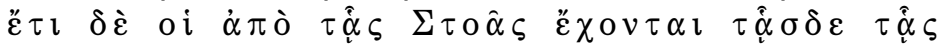
$\delta \iota \alpha \imath \rho \varepsilon \sigma \varepsilon \omega \varsigma$ (CHRYs. II 38)

[Coisa mais acabada são] os que disseram que da filosofia existe o físico, o ético, o lógico. [...] Já em palavras importaram-se dessa divisão Xenócrates e os peripatéticos, bem como os estóicos;

'Quemadmodum' inquit 'est aliqua pars philosophiae naturalis, est aliqua moralis, est aliqua rationalis [...] '(SEN. Ep. 88 24; cf. DL 7 39; SEXT. L. 1 19)

"Assim como" diz [Posidônio] "uma parte da filosofia é natural, uma é moral, uma é racional [...]".

Depois, definem cada parte, atribuindo à ética o escrutínio do comportamento humano, à física a investigação dos fenômenos naturais, à lógica a agudeza do discernimento e a propriedade do discurso, necessárias às anteriores ${ }^{7}$; assim Crisipo:

$\Delta \imath^{\prime} \ddot{\eta} \nu \alpha i \tau i \alpha \nu \kappa \alpha i ̀ \tau \rho \imath \mu \varepsilon \rho \dot{\eta} \varsigma \dot{\varepsilon} \sigma \tau \imath \nu \dot{\eta} \varphi \imath \lambda o \sigma o \varphi \hat{\imath} \alpha, \mathrm{Z}_{\varsigma}$

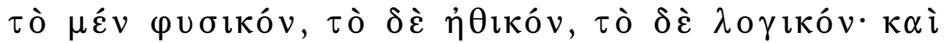

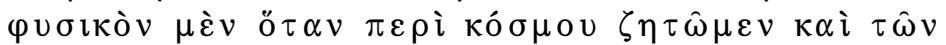

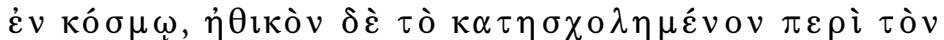

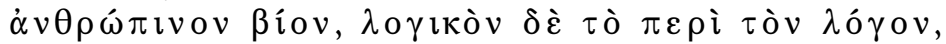
ö $\kappa \alpha \grave{\imath} \delta \imath \alpha \lambda \varepsilon \kappa \tau \imath \kappa o ̀ v ~ \kappa \alpha \lambda o v ̂ \sigma \imath v$ (Chrys. II 35; cf. PLUT. M. 874 e)

Por essa causa também é tripartida a filosofia, da qual [existe] o físico, o ético, o lógico, e físico quando se investiga [algo] acerca do mundo e do que há no mundo, ético o vacar à vida humana, lógico o [vacar] à lógica a que também chamam [os estóicos] dialético;

assim Sêneca (séc. I d.C.):

Philosophiae tres partes esse dixerunt et maximi et plurimi auctores: moralem, naturalem, rationalem. Prima componit animum; secunda rerum naturam scrutatur; tertia proprietates verborum exigit et structuram et argumentationes, ne pro vero falsa subrepant (SEN. Ep. 89 9) 
Que da filosofia são três as partes: a moral, a natural, a racional, disseram-no tanto grandes como freqüentes autores. A primeira compõe o ânimo; a segunda escruta a natureza das coisas; a terceira debate as propriedades das palavras, a estrutura, as argumentações, para que se não insinue o falso como verdadeiro.

Depois, dispõem as partes; aqui, porém, há discrepância nos testemunhos. Pois, segundo Plutarco (séc. I-II d.C.), Crisipo reservaria a primeira posição à lógica, a segunda à ética, a terceira à física:

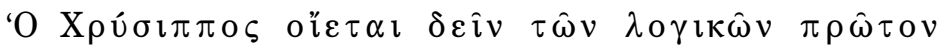

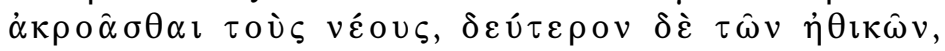

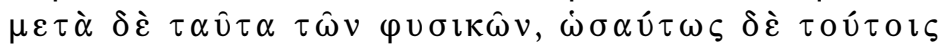

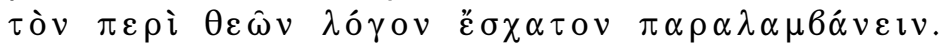

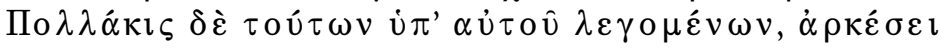

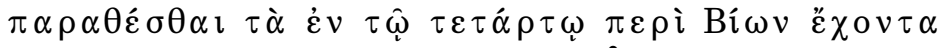

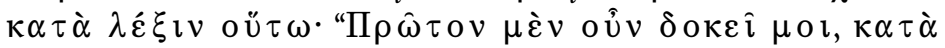

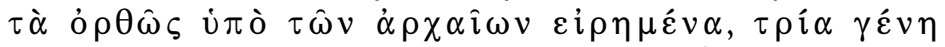

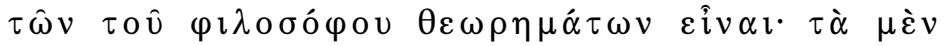

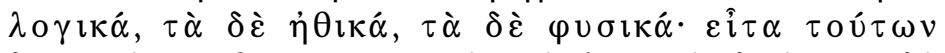
$\delta \varepsilon \hat{\imath} \nu \tau \alpha \tau \tau \varepsilon \sigma \theta \alpha \imath \pi \rho \hat{\omega} \tau \alpha \mu \grave{\varepsilon} \nu \tau \grave{\alpha} \lambda \sigma \gamma \imath \kappa \dot{\alpha}, \delta \varepsilon v i \varepsilon \rho \alpha \delta \grave{\varepsilon}$

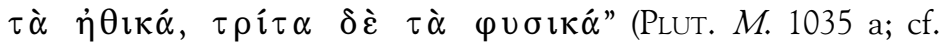
CHRYs. II 42)

Crisipo pensa que os novatos devem primeiro ouvir [falar] das coisas lógicas, em segundo das éticas, depois destas das físicas; que, assim, é para esses receberem por último o arrazoado acerca dos deuses. Ora, tendo ele falado isso aqui e ali, bastará expor o que [está] no quarto [livro] de Sobre as vidas, tendo à letra isto: "Primeiro, pois, parece-me, conforme o que corretamente os antigos disseram, ser três os gêneros das especulações do filósofo: o lógico, o ético, o físico. Então, desses deve-se dispor em primeiro o lógico, em segundo o ético, em terceiro o físico".

Desse testemunho, aliás, pode-se inferir que é em Crisipo que pensa Sexto Empírico quando diz, genericamente, que os estóicos dispõem primeiro a lógica, depois a ética, depois a física:

Oi $\delta \grave{\varepsilon} \dot{\alpha} \pi \grave{o} \tau \hat{\alpha} \varsigma \Sigma \tau o \hat{\alpha} \varsigma \kappa \alpha \grave{\imath} \alpha \dot{\tau} \tau o \grave{\imath} \alpha \rho \chi \varepsilon \imath \nu \mu \varepsilon v \quad \varphi \alpha \sigma \imath$

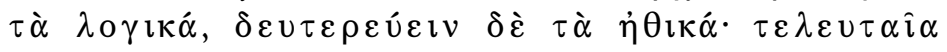


$\delta \grave{\varepsilon} \quad \tau \varepsilon \tau \dot{\alpha} \chi \theta \alpha \imath \quad \tau \grave{\alpha} \quad \varphi v \sigma \imath \kappa \dot{\alpha} . \quad \pi \rho \hat{\omega} \tau o v \quad \gamma \grave{\alpha} \rho \quad \delta \varepsilon \hat{\imath} \nu$

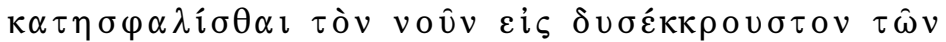
$\pi \alpha \rho \alpha \delta \imath \delta o \mu \varepsilon v \omega v \varphi \nu \lambda \alpha \kappa \eta \dot{v} \cdot \dot{o} \chi v \rho \omega \tau \imath \kappa o ̀ v \delta \dot{\varepsilon} \varepsilon \hat{\imath} v \alpha \imath \tau \hat{\alpha} \varsigma$ $\delta \imath \alpha v o i ́ \alpha \varsigma$ òv $\delta \imath \alpha \lambda \varepsilon \kappa \tau \imath \kappa o ̀ v ~ \tau o ́ \pi o v \cdot \delta \varepsilon u ́ \tau \varepsilon \rho o v \delta \grave{\varepsilon}$

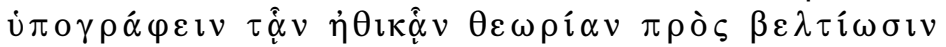

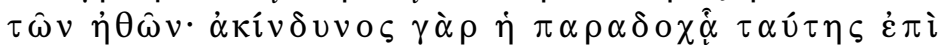

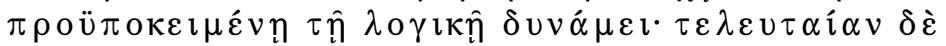

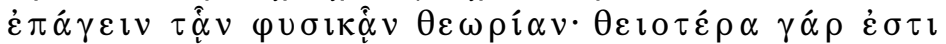
$\kappa \alpha \grave{\imath} \beta \alpha \theta u \tau \dot{\varepsilon} \rho \alpha \varsigma \delta \varepsilon \hat{\imath} \tau \alpha \imath \tau \hat{\alpha} \varsigma \dot{\varepsilon} \pi \imath \sigma \tau \dot{\alpha} \sigma \varepsilon \omega \varsigma$ (SEXT. L. 122 3; cf. CHRYs. II 44)

Quanto aos estóicos, também eles declaram ser o lógico o princípio, seguir-se[-lhe] o ético, dispor-se como acabamento o físico. Pois primeiro deve fazer-se inabalável o intelecto para inconcussamente guardar o transmitido [a ele], e o tenaz da inteligência é o lugar dialético. Em segundo [deve] inscrever-se a especulação comportamental [=ética] para habilitar-se os comportamentos, pois sem perigo é sua recepção [quando] sobre a potência racional subjacente. [Deve] introduzir-se como acabamento a especulação física, pois mais divina é e necessita de atenção mais profunda.

Segundo Diógenes Laércio, porém, o mesmo Crisipo, bem como Zenão de Cício e Êudromo, reservaria a primeira posição à lógica, a segunda à física, a terceira à ética:

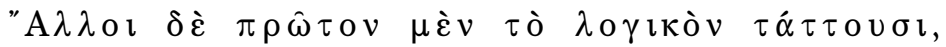

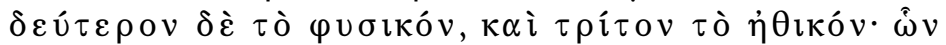

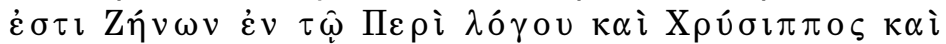
[...] "Ev $\delta$ ро $\mu$ о (DL 740 ; cf. Zen. I 46; ChrYs. II 43; Eudr. III 2) Já outros dispõem primeiro o lógico, em segundo o físico, em terceiro o ético; naqueles estão Zenão, no Do lógos, Crisipo [...] e Êdromo.

Enfim, sobre repartir a filosofia e, daí, nomear, definir e dispor-lhe as partes, Aristão (séc. IV-III a.C.), e não outros, ainda seleciona estas, de modo a excluir a física e a lógica e conservar tão somente a ética ${ }^{8}$ :

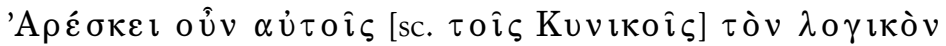
$\kappa \alpha \grave{i} \tau o ̀ v ~ \varphi v \sigma \imath \kappa o ̀ v ~ \tau o ́ \pi o v ~ \pi \varepsilon \rho \imath \alpha \imath \rho \varepsilon \hat{\imath} v, \dot{\varepsilon} \mu \varphi \varepsilon \rho \hat{\omega} \varsigma$

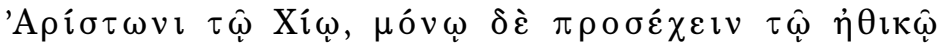
(ARIST. I 354) 
Agrada, pois, aos mesmos [cínicos] suprimir o lugar lógico e o físico, aproximando-se [assim] a Aristão de Quios, e ater-se unicamente ao ético;

e justifica a seleção, arrazoando que a física estuda coisas que estão além de nós, e a lógica, coisas que estão aquém, e que só a ética estuda coisas nossas?:

Tóv $\tau \grave{\varepsilon} \varphi$ u

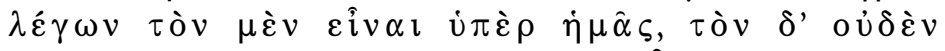
$\pi \rho$ ò $\varsigma \dot{\eta} \mu \hat{\alpha} \varsigma, \mu$ óvov $\delta \grave{\varepsilon} \tau$ òv $\dot{\eta} \theta \imath \kappa o ̀ v \varepsilon \hat{i} v \alpha \imath \pi \rho \grave{o} \varsigma \dot{\eta} \mu \hat{\alpha} \varsigma$ (id. I 351)

Suprime [Aristão] o lugar físico e o lógico, arrazoando que aquele está além de nós, que este nada tem conosco, que o ético é o único que se tem a nós;

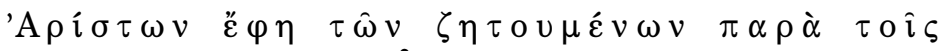
$\varphi \imath \lambda o \sigma o ́ \varphi$ ol $\varsigma \tau \grave{\alpha} \mu \grave{\varepsilon} \nu \varepsilon \hat{\imath} v \alpha \imath \pi \rho \grave{s} \varsigma \dot{\eta} \mu \hat{\alpha} \varsigma, \tau \grave{\alpha} \delta \grave{\varepsilon} \mu \eta \delta \grave{\varepsilon} \nu$ $\pi \rho \grave{o} \varsigma \dot{\eta} \mu \hat{\alpha} \varsigma, \tau \grave{\alpha} \delta^{\prime} \dot{v} \pi \dot{\varepsilon} \rho \dot{\eta} \mu \hat{\alpha} \varsigma$. $\pi \rho \grave{o ̀} \varsigma \dot{\eta} \mu \hat{\alpha} \varsigma \tau \grave{\alpha} \dot{\eta} \theta \iota \kappa \dot{\alpha}$, $\mu \dot{\alpha} \quad \pi \rho \grave{o} \varsigma \quad \dot{\eta} \mu \hat{\alpha} \varsigma \quad \delta \grave{\varepsilon} \quad \tau \grave{\alpha} \quad \delta \imath \alpha \lambda \varepsilon \kappa \tau \imath \kappa \dot{\alpha} \quad(\mu \dot{\alpha} \quad \gamma \dot{\alpha} \rho$ $\sigma u \mu 6 \alpha \dot{\alpha} \lambda \lambda \varepsilon \sigma \theta \alpha \imath \pi \rho$ ò $\varsigma \dot{\varepsilon} \pi \alpha \nu$ ó $\rho \theta \omega \sigma \iota v \beta$ íou) $\dot{v} \pi \dot{\varepsilon} \rho \dot{\eta} \mu \hat{\alpha} \varsigma$

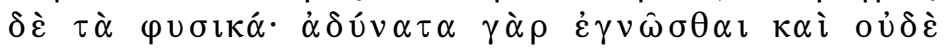
$\pi \alpha \rho \varepsilon \chi \varepsilon \imath \nu \chi \rho \varepsilon i \alpha \nu$ (id. I 352)

Declarava Aristão que das coisas investigadas pelos filósofos umas se têm a nós, outras nada têm conosco, outras estão além de nós: têm-se a nós as éticas; não se têm a nós as dialéticas [=lógica], pois não se coadunam com a correção da vida [=ética]; além de nós [estão] as físicas, pois [são] impossíveis de se conhecer e não apresentam utilidade;

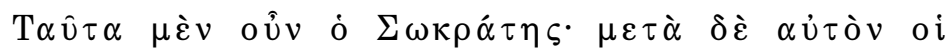

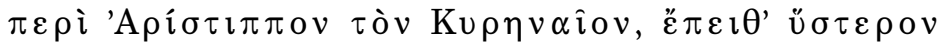

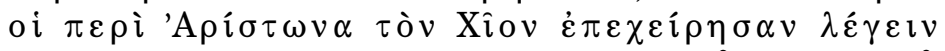

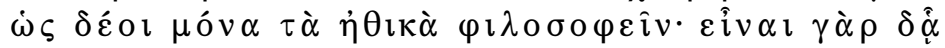
$\tau \alpha \hat{v} \tau \alpha \mu \grave{\varepsilon} v \delta v \nu \alpha \tau \grave{\alpha} \kappa \alpha \grave{i} \phi \dot{\varepsilon} \lambda \imath \mu \alpha \cdot \tau$ o v̀ $\varsigma \mu \varepsilon v \tau$ ol $\pi \varepsilon \rho \grave{i}$

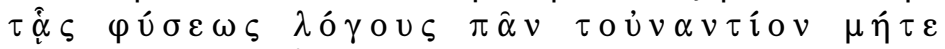

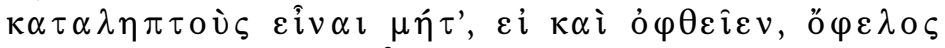

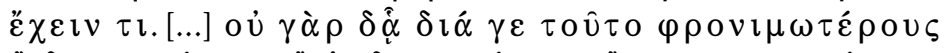

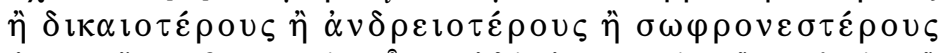

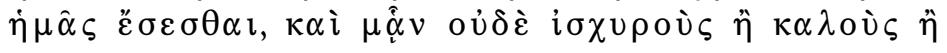




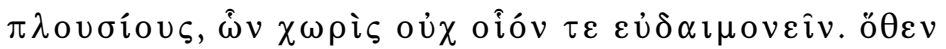

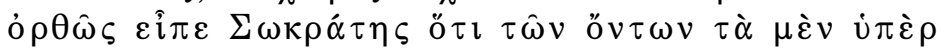

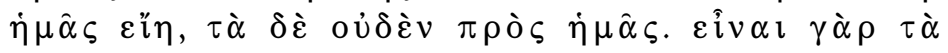
$\varphi v \sigma \imath \kappa \grave{\alpha} \mu \grave{\varepsilon} v$ ن $\pi \grave{\varepsilon} \rho \dot{\eta} \mu \hat{\alpha} \varsigma, \tau \grave{\alpha} \delta \grave{\varepsilon} \mu \varepsilon \tau \grave{\alpha} \tau \grave{o} v \theta \dot{\alpha} v \alpha \tau o v$

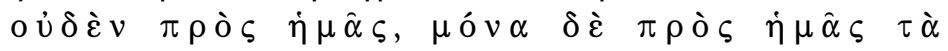

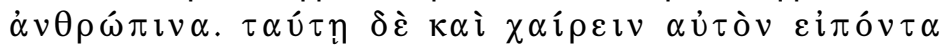

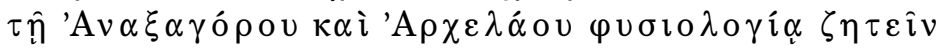

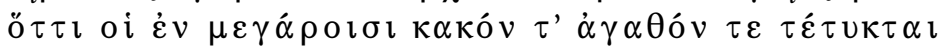
(id. I 353)

Estas coisas, pois, Sócrates; depois dele, os de Aristipo de Cirene; a seguir, enfim, os de Aristão de Quios pegaram a arrazoar: que as coisas éticas são as únicas que se devem filosofar, pois decerto estas seriam possíveis e úteis; entrementes, os arrazoados acerca da natureza [= física], bem ao contrário, nem seriam apreensíveis nem, mesmo se se pudessem admirar, teriam algo útil. [...] Pois decerto nós não haveríamos de ser por isso mais prudentes ou mais justos ou mais valorosos ou mais sóbrios e nem mais fortes ou mais belos ou mais ricos, sem o que não é possível ser bem-fadado. Daí [vem que] Sócrates diz corretamente que do que existe umas coisas estão além de nós, outras nada têm conosco; pois as físicas estariam além de nós, e as de depois da morte nada teriam conosco, e as únicas que teriam a nós seriam as humanas [=ética]. Assim, pois, ele, dizendo adeus ao estudo natural de Anaxágoras e Arquelao, investigava "que mal que bem em casa te foi feito" [Hom. O. 4 392];

Liber igitur a tali irrisione Socrates, liber Aristo Chius, qui nihil istorum [sc. physicorum] sciri putat posse (id. I 355)

Livre, pois, de tal irrisão Sócrates, livre Aristão de Quios, que calcula que de nada desses [físicos] se pode ter ciência;

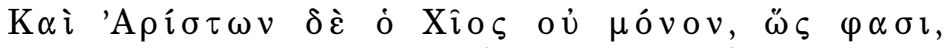

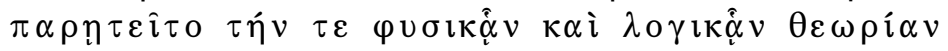
$\delta \mathrm{l} \grave{\alpha} \quad \tau \grave{o} \quad \dot{\alpha} v \omega \varphi \varepsilon \lambda \grave{\varepsilon} \varsigma \quad \kappa \alpha \grave{i} \pi \rho \grave{o} \varsigma \quad \kappa \alpha \kappa o \hat{v} \quad \tau$ oî $\zeta$

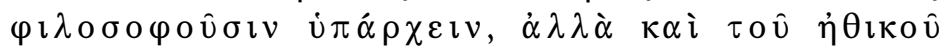

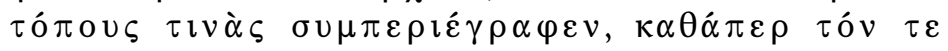

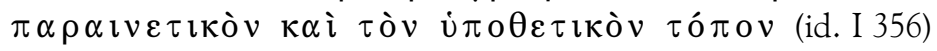

E também Aristão de Quios não só, como declaram, apunha a especulação física e lógica, por ser inútil e princípio de mal[es] para 
os que filosofam, mas também proscreveu alguns lugares do ético, tais como o lugar parenético e o hipotético;

Ariston Chius non tantum supervacuas esse dixit naturalem et rationalem [sc. partem philosophiae] sed etiam contrarias. moralem quoque, quam solam reliquerat, circumcidit. nam eum locum, qui monitiones continet, sustulit et paedagogi esse dixit, non philosophi, tamquam quicquam aliud sit sapiens quam generis humani paedagogus (id. I 357)

Aristão de Quios disse ser não só supérfluas [as partes] natural e racional, mas ainda contrárias. Também a moral, que deixara só, entrecortou. Pois sustentou aquele lugar que contém admoestações e disse ser ele do pedagogo, não do filósofo, como se o sábio fosse algo outro que o pedagogo do gênero humano.

\subsection{Em Aristóteles}

Antes dos estóicos, porém, já Aristóteles (séc. IV a.C.) considera a tripartição da filosofia, pois assim distingue três epistémai:

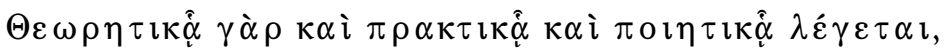

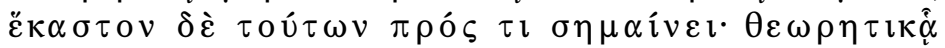

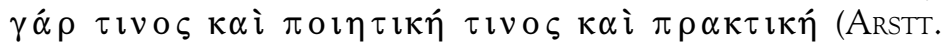
Top. 66145 a 15-8; cf. 81157 a 10-2)

Pois diz-se [a ciência] especulativa, atuativa e ficcional, e cada um desses [dizeres] acena para algo, pois [é] especulação de algo, ficção e ação de algo;

assim distingue três diánoiai:

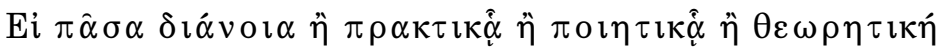 (id. Met. 511025 b 25; cf. Nic. 621139 a 27-8)
Se toda inteligibilidade é ou prática ou poética ou teorética;

assim distingue três protáseis e problémata:

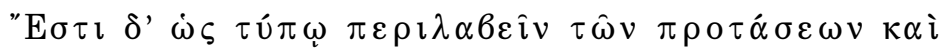
$\tau \hat{\omega} \nu \pi \rho \circ b \lambda \eta \mu \alpha \tilde{\alpha} \omega \nu \mu \hat{\varepsilon} \rho \eta \tau \rho \hat{\imath} \alpha$. Ai $\mu \grave{\varepsilon} \nu \gamma \grave{\alpha} \rho \dot{\eta} \theta \imath \kappa \alpha \grave{\imath}$ 


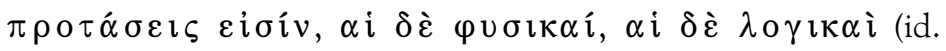
Top. 114105 b 19-21)

Das proposições e problemas, para que em esboço se compreendam, existem três partes, pois existem as proposições éticas, as físicas, as lógicas.

\section{A tripartição da filosofia em Platão e Sócrates}

Mas a tripartição da filosofia já estaria em Platão, se não em Sócrates, a julgar, primeiro, pelas lições de muitos autores antigos ou tardios e, depois, por um passo dos Diálogos, como se pretende mostrar a seguir.

\subsection{Fora dos Diálogos}

Aristóteles diz que Platão, primeiro familiarizado com as opiniões de Crátilo e Heraclito sobre o sensível [teórica] (ARstT. M. 16987 a 32-5), depois concorde com Sócrates, que fez caso do comportamental [prática] e não da natureza [teórica] (id. ib. 16987 b 1-4; cf. Part. an. 11642 a 24-31), acabou por reunir as lições deste e daqueles (id. M. 16987 b 4-6); em outras palavras, Platão teria harmonizado as partes física, de Crátilo e Heraclito, e ética, de Sócrates. Porém, é de reparar que Crátilo, tido, na Metafísica de Aristóteles, por representante da parte física, pois que par de Heraclito (id. ib. 35 1010a 10-5), aparece, no diálogo homônimo de Platão, a discutir sobre a correção dos nomes (PlAt. Crat. 384 a), o que seria matéria da lógica; demais, o mesmo diálogo é qualificado por Diógenes Laércio como lógico (DL 3 58; cf. Proleg. 1026 36-9). Assim, poder-se-ia pensar, já com Aristóteles já com Platão, que o discípulo de Sócrates recolheu do mestre as lições de ética, e de Heraclito, as de física; já de Crátilo teria recolhido as de lógica.

Cícero, ao dizer, nos Academica posteriora, que é convenção ensinar a filosofia segundo uma ratio triplex:

Una de vita et moribus, altera de natura et rebus occultis, tertia de disserendo et [...] iudicando (Cic. Ac. 15 19)

A primeira da vida e costumes [=prática], a segunda da natureza e coisas ocultas [=teórica], a terceira do discurso e [...] juízo [=lógica], 
diz que tal convenção foi aceita por Platão. Demais, diz no Bruto que Sócrates, rejeitando as partes física e lógica, propugnou pela ética ${ }^{10}$ (id. Br. 8 31). Assim, Cícero opõe Sócrates, de um lado, aos sofistas, representantes da lógica, e, de outro, aos primeiros filósofos gregos, representantes da física ${ }^{11}$ :

His opposuit sese Socrates, qui subtilitate quadam disputandi refellere eorum instituta solebat. [...] Primumque tum philosophia, non illa de natura, quae fuerat antiquior, sed haec, in qua de bonis rebus et malis deque hominum vita et moribus disputatur, inventa dicitur (id. Br. 8 31; cf. Tusc. $348 ; 54$ 10)

A esses [sofistas] opôs-se Sócrates, que, com disputa algo sutil, soía refutar-lhes as teses. [...] Pela primeira vez, então, inventou-se, dizem, a filosofia, não a da natureza, que fora a antiga, mas a que disputa sobre as coisas boas e más, bem como da vida e costumes dos homens.

Assim, poder-se-ia pensar, com Cícero, que Platão recolheu dos sofistas as lições de lógica; dos primeiros filósofos gregos, as de física; de Sócrates, as de ética.

Mas é com os platônicos que muitos pensam a relação entre Platão e a tripartição da filosofia. Platônicos do séc. II d.C. afirmam, primeiro, a primazia de Platão na tripartição da filosofia, como, em grego, Ático:

${ }^{\circ} \mathrm{O} \tau \imath \mu \grave{\varepsilon} v \Pi \lambda \dot{\alpha} \tau \omega \nu \pi \rho \hat{\omega} \tau$ o $\varsigma \kappa \alpha \grave{\imath} \mu \alpha \dot{\alpha} \imath \sigma \tau \alpha \sigma v v \alpha \gamma \varepsilon \hat{\imath} \rho \alpha \varsigma$

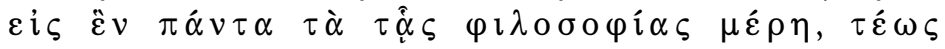

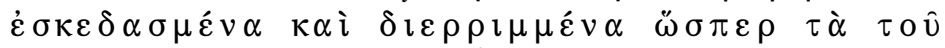
$\Pi \varepsilon \nu \theta \dot{\varepsilon} \omega \varsigma \mu \varepsilon \dot{\varepsilon} \lambda \eta, \kappa \alpha \theta \dot{\alpha} \pi \varepsilon \rho \varepsilon \hat{\imath} \pi \dot{\varepsilon} \tau \imath \varsigma, \sigma \hat{\omega} \mu \alpha \dot{\alpha} \tau \kappa \alpha \hat{\imath} \zeta \hat{\omega} \circ \nu$

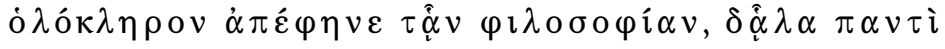
$\lambda \varepsilon \gamma o ́ \mu \varepsilon \nu \alpha$ (ATT. 12 2)

Que Platão, depois de por primeiro e maximamente congregar em unidade todas as partes da filosofia, até lá dispersas e espalhadas como os membros de Pênteu, conforme alguém disse [Num. 24], fez a filosofia parecer um corpo e vivente à parte, são dizeres claros a todos,

como, em latim, Apuleio:

[...] ut primus tripartitam philosophiam copularit, sibique invicem necessarias partes, neque pugnare inter se tantummodo, sed etiam mutuis adjuvare auxiliis ostenderit (APUL. Plat. 310, 4-7) 
[...] que foi [Platão] o primeiro que copulou a filosofia tripartida e demonstrou que as partes eram necessárias umas às outras e não apenas não pelejavam entre si mas ainda se ajudavam com auxílios mútuos;

Nam quoniam tres partes philosophiae congruere inter se primus obtinuit [...] (id. ib. 310, 30-2)

Pois já que foi [Platão] o primeiro que obteve a congruência das três partes da filosofia entre elas [...].

Depois, opõem a filosofia de Platão, total, às dos predecessores, parciais. Assim, Ático julga Platão por aquele que reuniu num todo a parte teórica, de Anaxímenes e outros, a prática, de Pítaco e outros, e a lógica, de Zenão de Eléia e outros:

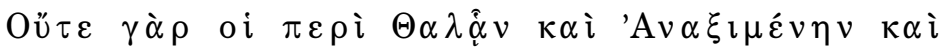

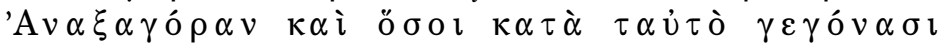

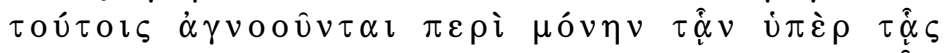

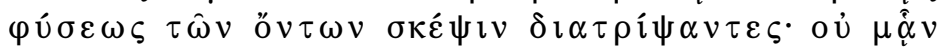

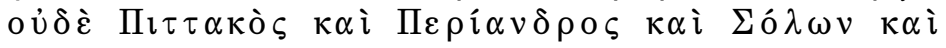

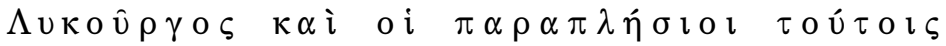

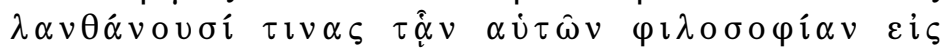

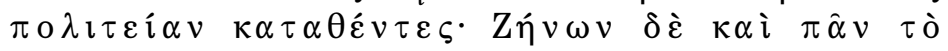

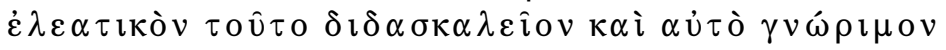

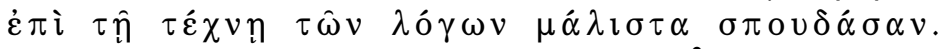

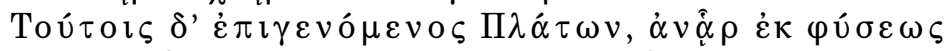

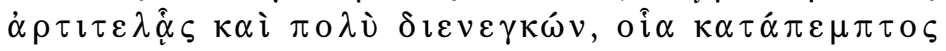

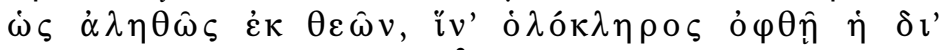

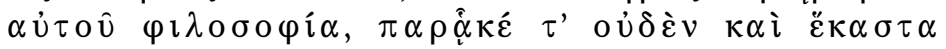

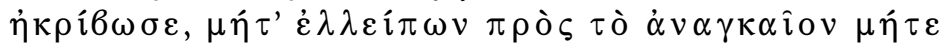

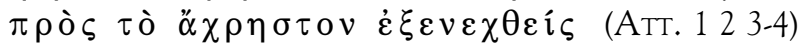

Pois ninguém ignora que os de Tales, os de Anaxímenes, os de Anaxágoras e cada um dos gerados nesses se entretêm com a simples inspeção da natureza dos seres [=teórica]; nem tampouco escapa a alguém que Pítaco, Periandro, Solon, Licurgo e os pares desses depõem sua filosofia na política [=prática]; já Zenão e toda a escola eleática também são conhecidos por ter-se aplicado maximamente à técnica dos arrazoados [=lógica]. Já Platão, sucessor desses, varão recém-iniciado e mui distinto, como que verdadeira- 
mente enviado dos deuses para que se visse à parte a filosofia dele, nada preteriu e cada coisa esmiuçou, nem deixando para o necessário, nem desviado para o inútil.

Já Apuleio julga que Platão reuniu numa só a filosofia natural de Heraclito, a moral de Sócrates e a intelectiva de Pitágoras:

Nam quamvis de diversis officinis haec ei essent philosophiae membra suscepta, naturalis ab Heracliteis, intellectualis a pythagoreis, moralis ex ipso Socratis fonte; unum tamen ex omnibus, et quasi proprii partus corpus effecit (Apul. Plat. 310, 7-11)

Pois se bem que de diversas oficinas houvesse recebido esses membros da filosofia: dos heracliteus os da natural, dos pitagoreus os da intelectiva, da fonte mesma de Sócrates os da moral, de todos, contudo, fez um corpo único e como que de paternidade própria;

Quapropter inventa Parmenidae ac Zenonis studiosius exsecutus, ita omnibus, quae admirationi sunt singula, suos libros explevit (id. ib. 310, 1-7)

Eis por que, após seguir com grande empenho as invenções de Parmênides e Zenão, de tal modo encheu seus livros com tudo que em si é para admirar.

Já nos Prolegômenos à filosofia de Platão, de anônimo do séc. VI d.C., lê-se que Platão, primeiro, usou da ética de Sócrates; depois, foi aos pitagóricos e, daí, ao heraclitiano Crátilo e o parmenidiano Hermipo:

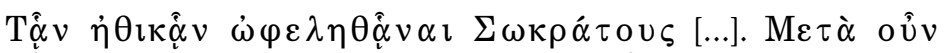

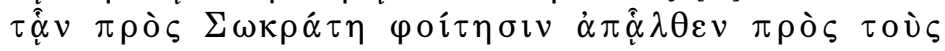
Пu$\theta \alpha \gamma o \rho \varepsilon i ́ o v$ [...]. 'Е

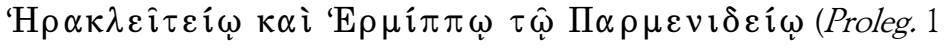
$333-45)$

Usou da ética de Sócrates [...]. Depois, então, de freqüentar Sócrates, foi até aos pitagóricos [...]. E freqüentou tanto o heraclitiano Crátilo como o parmenidiano Hermipo [=Hermógenes; cf. DL 3 6].

As lições dos platônicos são seguidas, então, por outros, embora às vezes modificadas; pois tomam Platão ora por aquele que reuniu numa filosofia total as 
${ }^{\prime} \mathrm{E} \varphi \imath \lambda \circ \sigma o ́ \varphi \eta \sigma \varepsilon \delta \grave{\varepsilon} \Pi \lambda \hat{\alpha} \tau \omega \nu[\ldots] \gamma \nu \eta \sigma i \omega \varsigma \kappa \alpha \grave{\imath} \tau \varepsilon \lambda \varepsilon \dot{\imath} \omega \varsigma$.

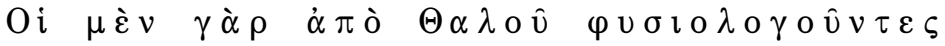
$\delta \imath \varepsilon \tau \varepsilon \lambda \varepsilon \sigma \alpha \nu \cdot$ oi $\delta \grave{\varepsilon} \pi \varepsilon \rho \grave{i} \Pi v \theta \alpha \gamma o ́ \rho \alpha \nu \dot{\alpha} \pi \varepsilon \kappa \rho u ́ \psi \alpha \nu \tau o$

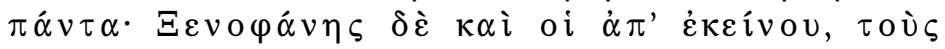

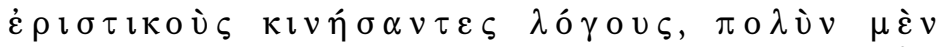

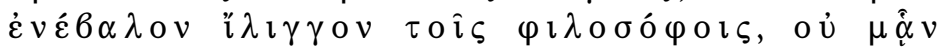

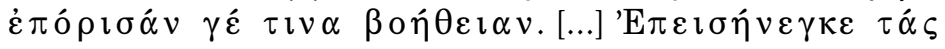

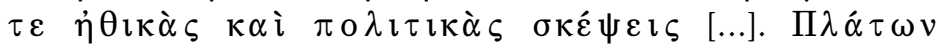

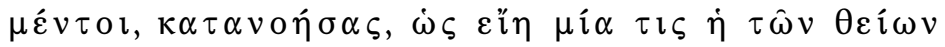
$\kappa \alpha \grave{i} \dot{\alpha} \nu \rho \omega \pi \hat{\imath} \nu \omega \nu \dot{\varepsilon} \pi \imath \sigma \tau \dot{\eta} \mu \eta, \pi \rho \hat{\omega} \tau$ os $\delta \imath \varepsilon \hat{\imath} \lambda \varepsilon, \kappa \alpha \grave{\imath} \ddot{\varepsilon} \varphi \eta$

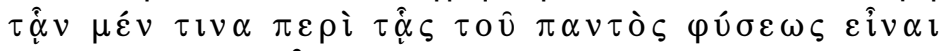
$\pi \rho \alpha \gamma \mu \alpha \tau \varepsilon \dot{\imath} \alpha \nu, \tau \hat{\alpha} \nu \delta \grave{\varepsilon} \pi \varepsilon \rho \grave{i} \tau \hat{\omega} \nu \dot{\alpha} \nu \theta \rho \omega \pi \hat{\imath} \nu \omega \nu, \tau \rho i ́ \tau \nu$ $\delta \grave{\varepsilon} \tau \hat{\alpha} \nu \pi \varepsilon \rho \grave{i} \tau o u ̀ s ~ \lambda o ́ \gamma o u \varsigma$ (Eus. Praep. 112 )

Ora, Platão filosofou [...] de modo genuíno e acabado. Pois os próximos a Tales, ao arrazoar sobre a natureza [=física], completaram-se; os circunstantes a Pitágoras cobriram as coisas todas [ $=$ física]; Xenófanes e os próximos a este, ao incitar as disputas lógicas, lançaram muita reviravolta aos filósofos, não abriram nenhuma passagem. [...] Introduziu [Sócrates] os exames éticos e políticos [...]. Platão, entrementes, tendo entendido que era única a ciência das coisas divinas e humanas, foi o primeiro que [a] distinguiu, declarando existir uma cogitação de toda a natureza [=física], a das coisas humanas [=ética], a terceira dos arrazoados [= lógica];

e Fócio:

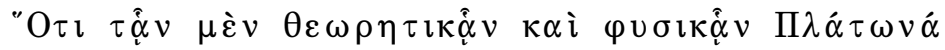

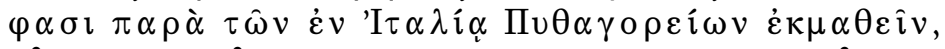

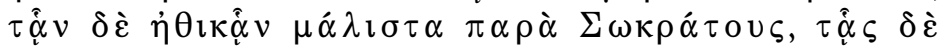

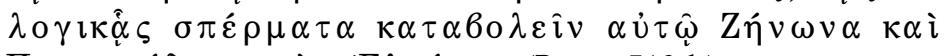

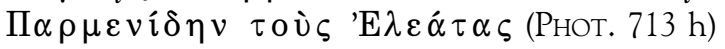

Isto declaram: que a disciplina especulativa e física Platão aprendeu junto aos pitagoreus da Itália, e a ética, mais que tudo, junto a Sócrates, e da lógica lhe lançaram as sementes Zenão e Parmênides de Eléia.

Dos que se afastam dos platônicos, por tomar Platão, não pelo que unificou as partes da filosofia, mas pelo que contribuiu com a lógica para primeiro perfazer e depois unificar a filosofia, citam-se Agostinho (séc. IV-V d.C.) e Isidoro 
de Sevilha. Agostinho, que, na Cidade de Deus, atribui a tripartição da filosofia a Platão (Aug. Ciu. 8 4), diz que Sócrates, renunciando às questões da natureza [teórica], voltou toda a filosofia para as questões da moral [prática] (id. ib. 8 3), de modo que, se Pitágoras sobressaiu pela vida contemplativa, aquele, pela ativa (id. ib. 8 4; cf. nota 8). Mas se a parte natural [teórica] é representada por Pitágoras, e a moral [prática] por Sócrates, ao reunir ambas Platão mesmo passa a representante da racional [lógica] (id. ib. 8 4). Assim também refere Isidoro de Sevilha cada uma das partes da filosofia a um respectivo fundador, afora referir a antiga filosofia, não a Pitágoras, mas a Tales (ISID. Orig. 2 24 4-8) - na verdade, o mesmo Agostinho divide a antiga filosofia em itálica e jônica, a que associa, respectivamente, Pitágoras e Tales (Aug. Ciu. 8 2; cf. nota 11) -. João de Salesbury, por sua vez, recolhe ambas as lições no Metalógico com estas palavras:

\section{Tradunt ergo [...] Augustinus et Isidorus, quod Plato philosophiam perfecisse laudatur, physicae, quam Pythagoras; et ethicae, quam Isocrates [sic] plene docuerat, adjiciens logicam (SARESB. Met. 22) \\ É tradição, pois, [...] segundo Agostinho e Isidoro, que Platão é louvado por ter perfeito a filosofia, ao ajuntar à física, que Pitágoras [ensinara], e à ética, que Sócrates ensinara plenamente, a lógica.}

A seguir, porém, diz que Aristóteles desenvolveu a lógica de tal modo que angariou as honras de auctor desta (id. ib. 2 2; cf. Hug. Erud. 2 3). Por isso, talvez, o Opúsculo das sete artes, de autor anônimo do séc. XI d.C., associa a parte natural a Pitágoras, a moral a Sócrates e Platão, e a racional a Aristóteles (Sept. art. 1-6; cf. nota 11).

Tal é a fortuna da lição dos platônicos, se não, anteriores a esta, das de Cícero e Aristóteles. Agora, pois, é para buscar um passo dos Diálogos em que se apóiem todas essas lições. Antes, porém, pode-se fazer uma digressão para pensar, ainda com os platônicos, um modo de organizar o estudo de Platão de acordo com a tripartição da filosofia.

Os platônicos propõem, primeiro, que se divida o estudo da filosofia de Platão nas três partes em que se divide a filosofia mesma ${ }^{12}$; assim, Ático:

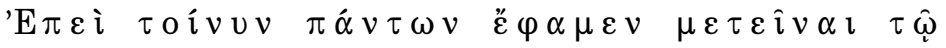

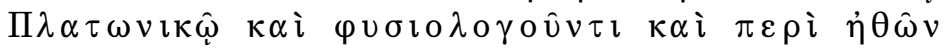

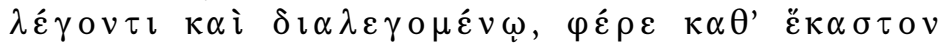
$\dot{\varepsilon} \pi \imath \kappa \varepsilon \psi \omega \dot{\omega} \mu \varepsilon \theta \alpha \quad$ (AтT. 12 5; cf. 24 1) 
Já que então dizíamos que tudo interessa ao platônico, quer fale da natureza [= teórica], quer fale sobre hábitos [=prática], quer sobre dialética [ =lógica], eia, inspecionemos cada coisa!;

assim, Apuleio:

Quae autem consulta, quae $\delta$ ó $\gamma \mu \alpha \tau \alpha$ a graece licet dici, ad utilitatem hominum, vivendique et intelligendi et loquendi rationem extulerit, hinc ordiemur (Apul. Plat. 310, 28-30)

Ora, aqueles conselhos, que em grego se podem dizer dógmata, para uso dos homens e exposição do estudo da vida [= prática], da intelecção [=teórica], da fala [=lógica]: por aí comecemos.

Alcínoo (séc. II d.C.), por sua vez, diz que é do mesmo Platão repartir-se o estudo da filosofia em três partes, que são, como diz, a théa tôn ónton kaì gnósis, ou "inspeção e conhecimento dos entes" [teórica], a práxis tôn kalôn, ou "ação do belo" [prática], e a toû lógou theoría, ou "especulação do arrazoado" [lógica] (AlcIN. 3153 25-30, 154 6-9).

Tal proposta consuma-se, então, com a sistematização dos vários diálogos de Platão, classificados e ordenados de acordo com as três partes da filosofia (cf. nota 12). Muitos são os sistemas ou cânones dos Diálogos, dos quais alguns se resumem a seguir. No séc. II d.C., o cânon de Albino (Alb. Intr. 5) qualifica como físico o Timeu; como ético, a Apologia; como lógico, o Teages, Crátilo, Lísis, Sofista, Laques e Político. A par dessas, propõe outras qualificações de acordo, já não com as partes da filosofia, mas com subpartes destas; assim, qualifica como elegktikós ou "refutativo" [=lógico] o Parmênides e Protágoras; como politikós ou "civil" [= prático], o Criton, República, Fedon, Minos, Simpósio, Leis, Epistolas, Epínomis, Menêxeno, Clitofontee Filebo; como peirastikós ou "experimental" [= lógico], o Eutífron, Menon, Ion e Cármides; como maieutikós ou "obstetrício" [=lógico], o Alcibíades; como anatreptikós ou "reverso" [= lógico], o Hipias, Eutidemo e Górgias.

Nos séc. III-IV d.C., o cânon de Jâmblico, primeiro, seleciona doze diálogos (cf. Proleg. 1026 16-44), que resumiriam toda a filosofia de Platão. Destes, então, toma dois, o Timeu e o Parmênides, como diálogos que resumem, respectivamente, toda a física e toda a teologia de Platão, isto é, como diálogos teóricos (ib. 16-21.434). Enfim, dos dez diálogos restantes, toma, primeiro, dois, o Alcíbiades e o Filebo, dispondo-os como textos que se devem ler, respectivamente, em primeiro e último lugar, pois no Alcíbiades aprenderíamos a conhecer-nos a nós mesmos, o que é o 
primeiro passo de nosso aprendizado, e no Filebo dialoga-se acerca do bem, que está acima de tudo e de tudo é acabamento (ib. 23-9). Toma, daí, os oito diálogos restantes, dispondo-os entre o Alcibíades e o Filebo assim: primeiro, dois práticos, que se subdividem em politikós ou "civil" (Górgias) e em kathartikós ou "purgativo" (Fedon); depois, dois lógicos, que se subdividem em perì onomáton ou "acerca dos nomes", isto é, gramatical (Crátilo), e em perì pragmáton ou "acerca dos casos", isto é, dialético (Teeteto); enfim, quatro teóricos, que se subdividem em physikoí ou "naturais" (Sofista e Político) e theologikoíou "teológicos" (Fedroe Simpósio) (ib. 2943). O cânon de Jâmblico é ainda observado por vários platônicos posteriores, tais como Proclo, do séc. V d.C. (Procl. Alc. 11 14-21; 177 19-22; Tim. 113 14-9; Theol. 1 8), e Olimpiodoro, do séc. VI d.C. (Olymp. Gorg. 6.1-6).

A par das sistematizações dos platônicos, é de reparar a de Diógenes Laércio. Este define os tipos de diálogos (DL 3 49) de acordo com os quais classifica, um a um, os diálogos de Platão (id. 3 50-1; cf. 59-61). Assim, há o diálogo hyphegetikós ou "dirigente" e o dzetetikós ou "investigador". Aquele se divide, de um lado, em theorematikós, que, por sua vez, se subdivide em physikós (Tim.) e logikós (Pol. Crat. Parm. Soph.), e, de outro, em praktikós, que, por sua vez, se subdivide em ethikós (Ap. Crito. Phaed. Phaedr. Conu. Menex. Clit. Ep. Phil. Hippa. Amat.) e politikós (Rsp. Leg. Min. Epin. Atl.). Já o diálogo dzetetikós se divide, de um lado, em gymnastikós, que, por sua vez, se subdivide em maieutikós(1-2Alc. Theag. Lys. Lach.) e peirastikós(Eutyphr. Men. Io. Charm. Theaet.), e, de outro, em agonistikós, que, por sua vez, se subdivide em endeitikós (Prot.) e anatreptikós (Euthyd. Gorg. Hipp.ma. Hipp.mi.). Quanto a Suidas (séc. X d.C.), tudo o que diz a respeito parece apoiarse em Diógenes Laércio, quer quando abona os tipos de diálogos de Platão com toda a sistematização de Diógenes (SuID. Diálogos) quer quando diz tão somente:

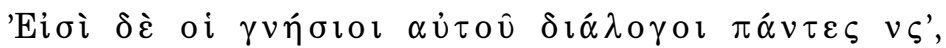

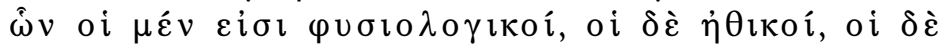

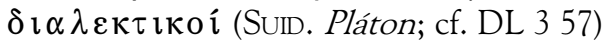

São os diálogos genuínos dele, ao todo, 56, dos quais uns são físicos, uns éticos, uns dialéticos.

\subsection{Nos Diálogos}

Enfim, é para buscar um passo dos mesmos Diálogos a que se possa referir a lição de Aristóteles e, daí, a de Cícero e, daí, as dos platônicos e scriptores 
artium. Ora, diz Eusébio, num passo que sói integrar a doxografia do estóico Aristão, que, ao ocupar-se Sócrates apenas da ética, se dedicava à única ocupação própria dos homens, já que as demais eram ou superiores ou inferiores a estes, e explica que as superiores são as questões acerca da física, as inferiores, aquelas acerca da lógica; mais que isso, porém, refere as questões acerca da natureza, em particular, a Anaxágoras (Eus. Praep. 15 62; Arist. I 353; cf. Xen. Mem. 11 13; 47 6.10; SeXt. L. 1 8; nota 9). Já Diógenes Laércio diz textualmente:

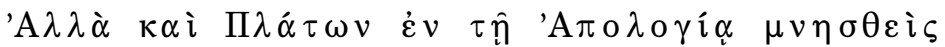

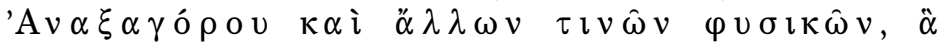

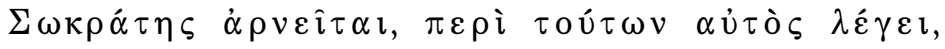
$\kappa \alpha i \pi \varepsilon \rho \dot{\alpha} \nu \alpha \tau \imath \theta \varepsilon i \varsigma \quad \pi \dot{\alpha} \nu \tau \alpha \Sigma \omega \kappa \rho \dot{\alpha} \tau \varepsilon \imath$ (DL 2 45)

Mas também Platão, ao recordar-se, na Apologia, de Anaxágoras e alguns outros físicos, fala sobre aquelas coisas que Sócrates repudiava, ainda que ele as referisse todas a Sócrates.
\end{abstract}

Enfim, o passo de Platão que sirva de apoio às lições sobrecitadas será a Apologia de Sócrates, em que, de fato, Sócrates, ao ser acusado por Meleto de tratar de questões da física, retruca dizendo, com ironia, que aquele o deve estar confundindo com Anaxágoras (Plat. Ap. 26 d; cf. Phaed. 98 b) - com Anaxágoras, conforme o mesmo Sócrates, ou, mais tarde, com o Pitágoras de Agostinho ou o Tales de Isidoro (cf. notas 10-1) - .

Mas atentemos, enfim, para as formulações precisas das partes da acusação e defesa que se lêem no texto de Platão. As acusações resume-as Sócrates nestes termos:

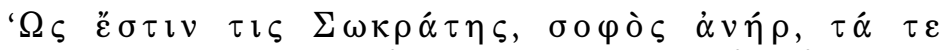
$\mu \varepsilon \tau \varepsilon \omega \rho \alpha \quad \varphi \rho o v \tau \imath \sigma \tau \dot{\alpha} \zeta \quad \kappa \alpha \grave{i} \quad \tau \dot{\alpha}$ i $\pi \grave{o} \quad \gamma \hat{\alpha} \zeta \quad \hat{\alpha} \pi \alpha \nu \tau \alpha$

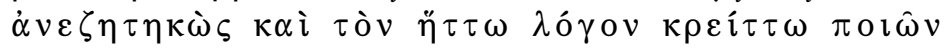
(Plat. Ap. 18 b; cf. 19 b)

Que existe certo Sócrates, homem sábio, que é meditador das coisas dos astros, que investigou tudo de sobre a terra [=teórica], que faz forte o arrazoado fraco [=lógica].

Os termos lembram, aliás, os que se empregam nas Nuvens de Aristófanes (séc. V a.C.). De fato, representa-se lá Sócrates a investigar os metéora prágmata ou "casos astrais" (AR. Nub. 218-34), e as personificações dos dois Arrazoados preten- 
dem ensinar a Estrepsíades como fazer que o arrazoado fraco triunfe do forte (id.

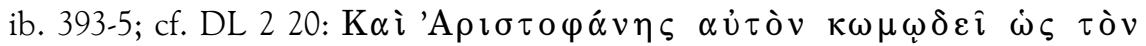

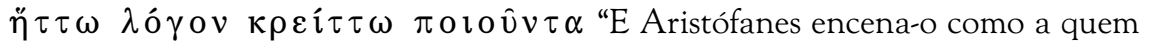
faz forte o arrazoado fraco").

Já a defesa resume-a dizendo que seu único saber é a anthrópine sophía ou "saber humano" (Plat. Ap. 20 d; cf. 23 a; Xen. Mem. 11 12), que consistiria em discorrer da areté ou "excelência" pelo escrutínio do indivíduo [prática] (PLAT. Ap. 38 a; cf. 30 b, 31 b, 41 e; Xen. Mem. 11 16).

Em suma, pelas formulações das partes da acusação e defesa, patenteia-se a parte da filosofia em que se insere Sócrates: não a parte teórica, que se ocupa da especulação da natureza, nem a lógica, que se ocupa da arte do raciocínio e eloqüência, mas a prática, que se ocupa do exercício da virtude. E depreenda-se da Apologia, enfim, que para Sócrates o único meio de tornar os homens phronimótatoi e béltistoi é torná-los, antes, áristoi (Plat. Ap. 36 c), de modo que, por isso, antes de os convidar a investigar os fenômenos da natureza ou incitar a manusear as armas da dialética e retórica, desafia-os a perscrutar a própria alma e conhecer-se a si mesmos.

\section{Conclusão}

Assim, haveria um sistema de partição da filosofia implicado na Apologia de Sócrates, o qual teria sido explicado pelos filósofos e scriptores artium gregos e latinos. Tal seria o sentido da lição de Sexto Empírico, que distingue entre Platão, de um lado, e Xenócrates, os peripatéticos e os estóicos, de outro, na medida em que, naquele, a tripartição da filosofia está em potencial (cf. SEXT. L. 1 16: dynámet) e, nos demais, em palavras (cf. id. ib.: rhetótata).

Demais, o método aqui empregado para averiguar a referida tripartição da filosofia na Apologia de Sócrates poder-se-ia empregar, ainda, para averiguar outras partições. Pois cada uma das referidas três partes da filosofia subdivide-se, por sua vez, em outras três, igualmente implicadas no texto de Platão. Por exemplo, se se aplicasse a progressão geométrica de ponto, linha e plano à subdivisão da parte prática da filosofia, obter-se-iam as partes relativas à ação do indivíduo [ponto], do grupo de indivíduos, ou família [linha], e do grupo de grupos de indivíduos, ou cidade ${ }^{13}$ [plano]; em outras palavras, obter-se-iam as partes ética, econômica [do gr. oîkos: "casa, família"] e política ${ }^{14}$ [do gr. pólis: "cidade"], respec- 
tivamente. Assim, tal partição ou, se se quiser, subtripartição lê-se, explicitamente, em Aristóteles e outros ${ }^{15}$; implicitamente, porém, já estaria em Platão. Pois assim como, na Apologia, Sócrates enuncia sua inserção na primeira tripartição da filosofia, assim numa segunda, ao dizer que abdicou dos afazeres públicos [política] (Plat. Ap. 36 b: demegorikôn; cf. 23 b: póleos) e de casa [economia] (id. ib. 36 b: oikonomías; cf. 23 b: oikeíon) para dedicar-se aos de si mesmo, ou do indivíduo [ética] (id. ib. 36 b: tôn heautou $\hat{u}^{16}$ ).

\title{
Notas
}

* Professor de Língua e Literatura Latina do Curso de Graduação da FFLCH-USP e Doutorando em Latim pelo Programa de Pós-Graduação em Letras Clássicas da FFLCH-USP.

1 Os termos gregos são assim vertidos ao latim. Pois, em primeiro lugar, assim como, em grego, theorikós deriva de theorós, isto é, "quem vê", e theoretikós de theoréo, isto é, "ver", assim, em latim, speculatiuus deriva de spicio, isto é, "ver"; assim também, theoría verte-se por speculatio, isto é, "especulação" [ação de ver], assim como, aliás, theorós por spectator, isto é, "espectador" [quem vê], e théatron, isto é, "teatro", por spectaculum, isto é, "espetáculo" [que é visto]. Às vezes, porém, emprega-se contemplatiuus por speculatiuus, de modo que alguns chegam mesmo a equiparar os termos latinos, como consta deste passo de Sêneca:

\section{Philosophia autem et contemplativa est et activa: spectat simul agitque (SEN. Ep. 95 10) \\ Ora, a filosofia tanto contemplativa é como ativa: especula e age si- multaneamente,}

ou deste de Agostinho:

\begin{abstract}
Quarum activa ad agendam vitam [...] pertinet, contemplativa autem ad conspiciendas naturae causas et sincerissimam veritatem (Aug. Ciu. 84)

Das quais [partes] a ativa pertence à ação da vida [...], já a contemplativa à inspeção das causas da natureza e da simplíssima verdade.
\end{abstract}

Em segundo lugar, assim como, em grego, praktikós deriva de prásso, isto é, "agir", assim, em latim, actiuus deriva de ago, isto é, "agir". Daí, se se vertem os termos gregos ao português por meio dos correspondentes latinos, obtêm-se as seguintes traduções: 
para theorikós, "especulativo" ou "especular", se não "contemplativo"; para praktikós, "ativo" ou "atuativo". Já o termo mekhanikós se traduziu ao latim por adulterinus, pois os scriptores artium faziam-no derivar de moikhós, isto é, "adúltero", quando, em rigor, o termo derivaria de mêkhos, isto é, "mecanismo", de modo a traduzir-se, mais propriamente, por "maquinal" (Hug. Erud. 19 ).

2 Hugo diz que o termo grego lógos pode verter-se ao latim tanto por sermo, ou "discurso", como por ratio, ou "razão", donde vem, aliás, que fale em logica sermotionalis e logica rationalis, isto é, "lógica discursiva" e "lógica racional" (Hug. Erud. 1 12); assim também João de Salesbury (SAREsB. Met. 1 10) e Isidoro de Sevilha (IsID. Orig. 24 7).

3 Avicena (séc. X-XI d.C.), ao sistematizar as partes da filosofia, explica a oposição entre especulação, modo teórico, e ação, modo prático. Segundo o filósofo iraniano, a parte teórica estuda coisas que não dependem da ação do homem, de modo que a este apenas caiba contemplá-las, por exemplo, os fenômenos da natureza; já a parte prática estuda coisas que justamente dependem daquela ação, por exemplo, as virtudes e vícios humanos (Avicena. O livro de ciência. Metafísica”.). Mas a explicação de Avicena apóia-se em Aristóteles, seja num passo da Metafísica (Arstr. M. 11993 b 20-1) seja noutros da Ética a Nicômaco (id. Nic. 111095 a 5; 221103 b 26-9; 1010 1179 a 35 - b 2). Cf. nota 9.

4 Os scriptores artium assim designam as partes da filosofia por termos que, em rigor, nomeiam os estudos próprios daquelas. Assim, por moralis (lat.), bem como por ethikós (gr.), isto é, "comportamental", nomeia-se o estudo do comportamento, ou melhor, das virtudes e vícios do homem, de que se ocupa a parte prática (cf. nota 3). Por naturalis (lat.), bem como por physikós (gr.), isto é, "natural", nomeia-se o estudo dos fenômenos da natureza de que se ocupa a parte teórica (cf. nota 3). Por rationalis (lat.), enfim, nomeia-se o estudo do juízo de que se ocupa a parte lógica (cf. nota 2). Tal modo de nomear, ademais, é legado estóico (cf. ZEN. I 45; Chrys. II 37-8; Diog. Bab. III 16; Apd. Sel. III 1; Eudr. 1; Sen. Ep. 88 24).

5 Este modo de dizer muito se aproxima ao de Agostinho, que fala em causa subsistendiou "causa da existência", ratio intellegendi ou "razão da intelecção", ordo vivendiou "ordem da vida" (Aug. Ciu. 8 4). Assim, pode-se depreender desses e de outros autores um vocabulário técnico adequado à exposição das três partes da filosofia. Do mesmo Agostinho, por exemplo, ainda se podem depreender os seguintes termos técnicos: para a parte ativa, a "ação da vida" (ad agendam vitam) ou "instituição dos costumes" (ad mores instituendos); para a contemplativa, a "inspeção das causas da natureza e da simplíssima verdade" (ad conspiciendas naturae causas et sincerissimam veritatem); ou então, para a ativa, o "fim de todas as ações" (finem omnium actionum); para a contemplativa, a "causa de todas as naturezas" (causam omnium naturarum); para a racional, o "lume de todas as razões" (lumen omnium rationum); ou então, os termos que se assinalam a seguir:

Si enim homo ita creatus est ut per id quod in eo praecellit adtingat illud quod cuncta praecellit, id est unum verum optimum Deum, sine quo nulla natura subsistit, nulla doctrina instruit, nullus usus expedit, ipse quaeratur ubi nobis serta sunt omnia, ipse cernatur ubi nobis certa sunt omnia, ipse diligatur ubi nobis recta sunt omnia 
Pois se o homem de tal modo foi criado que, por meio do que nele precede, atinja aquilo que ao conjunto das coisas precede, isto é, o Deus uno, verdadeiro, ótimo, sem o qual nenhuma natureza existe [=teórica], nenhuma doutrina instrui [=lógica], nenhuma utilidade aproveita [= prática], nele esteja a inquirição, onde nós temos a trama de tudo [=teórica]; nele o discernimento, onde nós temos a certeza de tudo [=lógica]; nele a dileção, onde nós temos a correção de tudo [=prática $]$.

6 O port. "parte" traduz o gr. méros. Outros termos gregos, porém, empregam os estóicos; Apolodoro de Seleucia, por exemplo, fala em tópoi ou "lugares" da filosofia (ApD. Sel. III 1); Crisipo (Chrys. II 37) e Êudromo (Eudr. III 1), em eíde ou "espécies"; outros, enfim, em géne ou "gêneros" (DL 7 39). Em latim, além de pars, que traduz méros, emprega-se locus por tópos (cf. Hier. Ep. 30 1); species por eídos (cf. IsiD. Orig. 224 3).

7 Ainda como definição, os estóicos comparam as partes da filosofia a partes de seres. Assim, uns, comparando a filosofia a um pomar, equiparam a física ao hasteamento das plantas, a ética ao ciclo dos pomos, a lógica à consistência dos muros; comparando a filosofia a um ovo, equiparam ética, física e lógica, respectivamente, a gema, clara e casca (SEXT. L. 1 17-8). Posidônio, porém, comparando a filosofia a um animal, equipara a física ao sangue e carne, a lógica aos ossos e nervos, a ética à alma (id. ib. 1 19; DL 7 40; Chrys. II 38-40). Outros, enfim, comparam a filosofia a uma cidade (DL 7 40).

8 Se isso se diz de Aristão em particular, Diógenes Laércio, porém, diz dos estóicos em geral que das três vidas por estes preceituadas, isto é, do bíos theoretikós, do praktikós e do logikós, ou "vida especulativa, ativa e racional", os estóicos elegeram a vida racional, por abraçar, como justificavam, as outras (DL 7 130).

9 O modo e termos com que Aristão justifica a seleção das partes da filosofia parecem irmanar-se com outros que Epicuro emprega na distinção entre coisas que dependem e coisas que independem de nós:

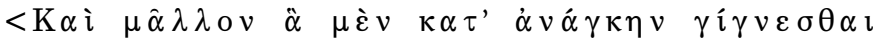

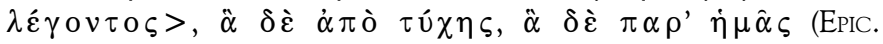 Men. 133) \\ E, mais, arrazoando gerar-se umas coisas conforme a necessidade, outras do acaso, outras por nós.}

Ambos, contudo, parecem filiar-se em Aristóteles:

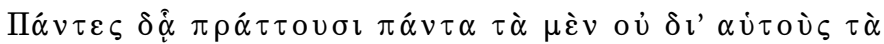
$\delta \grave{\varepsilon} \delta \imath^{\prime} \alpha \dot{u} \tau$ oús. $\tau \hat{\omega} v \mu \grave{\varepsilon} v$ oủv $\mu \hat{\alpha} \delta l^{\prime} \alpha \dot{u} \tau$ où $\zeta \tau \grave{\alpha} \mu \grave{\varepsilon} v \delta l \grave{\alpha}$ $\tau \dot{u} \chi \eta v \pi \rho \dot{\alpha} \tau \tau$ ov $\sigma \sigma \imath \tau \grave{\alpha} \delta$ ' $\dot{\varepsilon} \xi \dot{\alpha} v \dot{\alpha} \gamma \kappa \eta \varsigma$ (ARSTT. Rhet. 1107 $1368 \mathrm{~b})$

Todos, então, em tudo atuam, ou não por meio de si mesmos, ou por meio de si mesmos. No em que não por meio de si mesmos, ou atuam por meio do acaso, ou a partir da necessidade; 


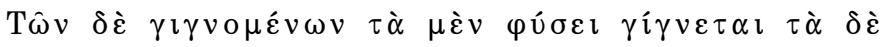
$\tau \dot{\varepsilon} \chi \nu \eta \tau \grave{\alpha} \delta \grave{\varepsilon} \dot{\alpha} \pi \grave{o} \tau \alpha \dot{u} \tau$ o $\mu \alpha \dot{\alpha} \tau$ ou (id. Met. 771032 a 12-3)

Do que se gera umas coisas são geradas pela natureza, umas pela arte, umas de moto próprio.

O mesmo Aristóteles, enfim, parece buscar a Platão o modo e termos de sua discussão:

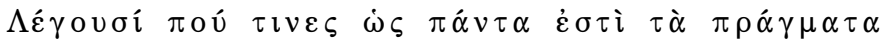

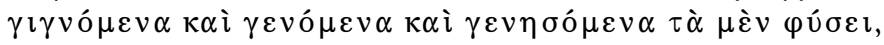
$\tau \grave{\alpha} \delta \grave{\varepsilon} \tau \dot{\varepsilon} \chi v \eta \eta$, $\tau \grave{\alpha} \delta \grave{\varepsilon} \delta i \grave{\alpha} \tau u ́ \chi \eta v$ (PLAT. Leg. $10888 \mathrm{e}$ )

Declaram alhures que todas as ações, que se geram e geraram e gerarão, existem umas por natureza, outras por arte, outras por meio do acaso.

10 Sobre isso é de reparar o que dizem, antes de todos, Xenofonte e Platão; pois Diógenes Laércio e Sexto Empírico são uníssonos em dizer que aquele nega, este afirma que Sócrates fosse dado à especulação da natureza (DL 2 45; Sext. L. 1 8-10; cf. Eus. Praep. 15 62). De fato, Xenofonte é taxativo ao declarar que Sócrates se absteve de especular as coisas da natureza (XEN. Mem. 11 11-6) e outras tais como as de geometria (id. ib. 47 2-3), astrologia (id. ib. 47 4) e astronomia (id. ib. 47 5-7). Já Platão faz Sócrates declarar expressamente que cobiçou, em jovem, o saber dos que estudavam a natureza (Plat. Phaed. 96 a; cf. 95 e - 99 d), tendo lido, então, os livros de Anaxágoras sobre tal matéria (id. ib. 98 b). Assim, Diógenes Laércio, se, de um lado, tem Sócrates pelo introdutor da ética na filosofia (DL 1 14), de outro, porém, diz que o mesmo Sócrates, além de ética, ensinou retórica:

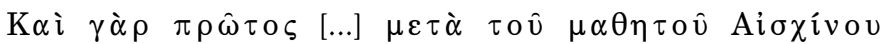

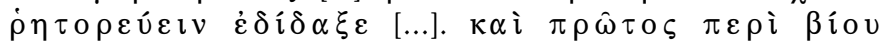
$\delta \iota \varepsilon \lambda \varepsilon \chi \theta \eta(\mathrm{id} .220)$

Foi [Sócrates] o primeiro que ensinou retórica [=lógica] [...]. E foi o primeiro que arrazoou acerca da vida [=ética],

e também física:

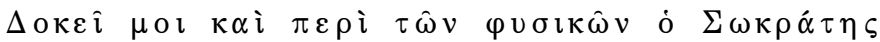
$\delta \imath \varepsilon \imath \lambda \varepsilon \chi \theta \alpha \imath$. ö $\pi$ ou $\gamma \varepsilon \quad \kappa \alpha \grave{\imath} \pi \varepsilon \rho \grave{\imath} \pi \rho$ ovoí $\alpha \varsigma \quad \tau \imath v \grave{\alpha}$

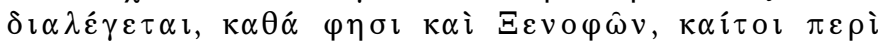

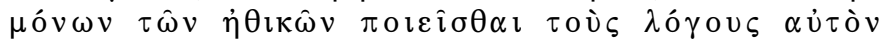
$\varepsilon i \pi \hat{\omega} \nu$ (id. 245 )

É opinião minha que também acerca de física arrazoou Sócrates, ao menos onde algo arrazoou acerca da providência, conforme declara 
também Xenofonte, ainda que dizendo que ele tenha feito arrazoados unicamente acerca de ética.

$11 \mathrm{Se}$ os testemunhos antigos concordam em estabelecer um único introdutor da ética na filosofia, Sócrates, o mesmo não fazem quando se trata do introdutor da física ou da lógica. Antes de tudo, porém, é de reparar que os antigos distinguem entre o inuentor, de um lado, e o auctor ou amplificator, de outro, isto é, entre quem descobre algo e quem desenvolve algo. Assim, Sócrates é para todos o representante da ética na filosofia porque dela é, a um tempo só, inuentor e amplificator. Da física, então, Cícero considera como inuentor e amplificator Pitágoras (Cic. Tusc. 54 10). Com ele concorda Agostinho (Aug. Ciu. 8 4), dele, porém, discorda Isidoro de Sevilha, que considera Tales (Isid. Orig. 224 4); já Arístocles considera ambos (Eus. Praep. 11 2), e Ático considera Tales, Anaxímenes e Anaxágoras (Aтt. 12 3). Quanto às subpartes da física, Heraclito é o que tratou dos naturalia ou aisthetá, isto é, do natural ou sensível, e Pitágoras, dos intellectualia ou noetá, isto é, do intelectível, como querem Apuleio (Apul. Plat. 310, 8-9) e Diógenes Laércio (DL 3 8). Da lógica, enfim, concordam os testemunhos antigos na medida em que distinguem entre o inuentor: Parmênides ou Zenão de Eléia, e o auctor ou amplificator: Platão ou Aristóteles. Assim, quanto ao inuentor, Aristóteles diz que é Zenão de Eléia o inventor (cf. DL 8 57: heureîn) e principiador (cf. SeXt. L. 1 7: arkhegós) da dialética (ARstT. Soph. Frag. 1), com o que parecem concordar Ático (Atт. 12 3) e Diógenes Laércio (DL 1 18). Já Apuleio se refere à lógica como ao invento de Parmênides e Zenão (Apul. Plat. 310, 2: inventa Parmenidae ac Zenonis), e Fócio diz que as sementes da lógica foram lançadas por Zenão e Parmênides (Рнот. 713 h). Outros, porém, apontam Platão, por exemplo, Diógenes Laércio (DL 3 56), Agostinho (Aug. Ciu. 8 4) e Isidoro de Sevilha (Isid. Orig. 224 7). Quanto ao amplificator ou auctor, enfim, uns dizem ser Platão (CAPEL. 4 330: amplitudinem), outros, Aristóteles (Sept. art. 6). A questão do inuentor e do amplificator ou auctor da lógica é, porém, assim resumida por Hugo de São Vítor:

In ea quoque dialectica primum inventa est a Parmenide, qui civitates et coetus hominum fugiens in rupe consedit non modico tempore, sicque dialecticam excogitavit [...]. Plato autem [...] in Aegyptum migravit, ibique perceptis liberalibus disciplinis. [...] Hic primus logicam rationalem apud Graecos instituit, quam postea Aristoteles discipulus ejus ampliavit, perfecit et in artem redegit (Hug. Erud. 32 )

Nele [sc. Egito] também a dialética foi inventada por Parmênides, que, fugindo à cidade e convívio com os homens, residiu como rupestre por não pouco tempo e, assim, excogitou a dialética [...]. Ora, Platão emigrou para o Egito, tendo lá recebido as disciplinas liberais. [...] Este [sc. Platão] foi o primeiro que instituiu a lógica racional junto aos gregos, a qual, depois, Aristóteles, discípulo dele, ampliou, perfez e agregou à arte; 
e por João de Salesbury:

Et licet Parmenides Aegyptius in rupe vitam egerit, ut rationes logices inveniret, tot et tantos studii habuit succesores, ut ei inventionis suae, totam fere praeripuerint gloriam. Tradunt ergo [...] quod Plato philosophiam perfecisse laudatur, physicae[...] et ethicae[...] adjiciens logicam [...]. Deinde Aristoteles artis regulas deprehendit et tradidit. Hic est Peripateticorum princeps, quem ars ista praecipuum laudat auctorem(SARESB. Met. 22)

E apesar de o egípcio Parmênides ter passado a vida como rupestre, para que inventasse os arrazoados da lógica, tantos e tamanhos sucessores do estudo [dele] houve que lhe surripiaram quase toda a glória de inventor daquela. É tradição, logo, [...] que Platão é louvado por ter perfeito a filosofia, ao ajuntar à física [...] e à ética [...] a lógica [...]. Daí, Aristóteles depreendeu e transmitiu as regras da arte. É ele o principiador dos peripatéticos que tal arte louva como precípuo autor.

Em suma, da ética é Sócrates inuentor e amplificator. Da física é, em geral, Pitágoras, se não Tales de Mileto, se não outros, e é, em particular, Pitágoras o das coisas intelectíveis, e Heraclito o das sensíveis. Da lógica o inuentor é Parmênides ou Zenão de Eléia, e o amplificator, Platão ou Aristóteles; de acordo com Hugo de São Vítor e João de Salesbury, porém, Parmênides seria quem a inventou no Egito; Platão, quem a introduziu na Grécia; Aristóteles, quem a ampliou.

12 Assim também os platônicos propõem que se divida o estudo de Aristóteles; daí vem que o corpus aristotelicum se organize em partes análogas às partes da filosofia, de modo a recolher-se, primeiro, as obras lógicas ou racionais (Categorias, etc.), depois, as teóricas ou especulativas (Física, etc.) e, enfim, as práticas ou atuativas (Ética a Nicômaco, etc.).

13 Pensar a pólis ou "cidade" como um grupo de oîkoi ou "famílias" é o que faz Arístoteles, ao referir-se àquela por meio do termo synoikía (ARstT. Pol. 1611 1), que em português se poderia ou desdobrar em "conjunto [syn-] de famílias [-oikía]" ou traduzir por "comunidade", "conglomeração", "consórcio".

14 Os termos gregos podem-se verter ao português pelo latim. Ora, em primeiro lugar, assim como em grego politikós deriva de pólis, isto é, "cidade", assim em latim urbanus e ciuilis derivam, respectivamente, de urbs e ciuitas, isto é, "urbe" e "cidade". Em segundo lugar, assim como em grego oikonomikós deriva de ổkos e nómos, isto é, "casa" e "lei", assim em latim domesticus deriva de domus, isto é, "casa". Em terceiro lugar, assim como em grego ethikós deriva de éthos, isto é, "comportamento", assim em latim moralis deriva de mos, isto é, "costume". As equiparações entre os termos gregos e latinos já são propostas por Cícero, que, assim, traduz politikós por ciuilis (CiC. Fin. 4 25; 523 66), oîkos por domus (id. Att. 1516 b), e éthos por mos (id. Fat. 1 1; Or. 37 128). 
Daí, se se vertem os termos gregos ao português por meio dos correspondentes latinos, obtêm-se as seguintes traduções: para politikós, "civil" ou "urbano"; para oikonomikós, "doméstico"; para ethikós, "moral".

15 Por exemplo, em Arstt. Nic. 681141 b 23 - 91142 a 10; Eud. 181218 b 12-4. Demais, assim como o corpus aristotelicum se organiza de acordo com a primeira tripartição da filosofia (cf. nota 12), assim as obras práticas ou atuativas de Aristóteles se organizam em obras políticas ou civis (Politica, Constituição de Atenas), econômicas ou domésticas (Economia) e éticas ou morais (Ética a Nicômaco, Ética a Eudemo, Grande morale Acerca de virtudes e vícios).

16 Como Platão, também Aristóteles designa a parte ética pela perífrase de tò hautoû, apondo-lhe, ademais, os termos oikonomía e politeía (Arstr. Nic. 691142 a 9-10).

SANTOS, M. M. dos. The threefold division of philosophy at Middle Ages and antiquity and her sources in Plato.

ABSTRACT: Imean to show how the two accusations that Socrates confutes in the Apology and the own defence that he corroborates are inserted in a system dividing and joing again the parts of philosophy. Therefore I begin with the divisions of philosophy proposed by the late scriptores artium and, little by little, I make them turn up to their ancient sources, that are, in general, in Greek and Roman philosophers and, in particular, in Plato, in the partys of accusation and defence presented in the Apology.

KEYWORDS: parts of philosophy; threefold division of philosophy; Plato; Apology. 